\title{
Application of biochar from palm oil plants residues on physical properties of Ultisol
}

\author{
Irfan Rusdi, Abdul Rauf, Supriadi, Benny Hidayat* \\ Agrotechnology Study Program, Faculty of Agriculture, USU, Medan 20155 \\ Corresponding Author: bendayat@gmail.com
}

\begin{abstract}
Ultisol is one type of soil that has several problems for plant growth. The main problems are poor physical properties such as high bulk density, low soil permeability, and low water retention ability. This research aim was to determine the effects of various application of biochar made of oil palm plants residue on bulk density and soil porosity of Ultisol soil. The research design used a non-factorial completely randomized design, consisting of 5 treatments, namely without biochar application (control), oil palm stem biochar, oil palm frond biochar, oil palm empty fruit bunches biochar and combination of biochar ingredients. Each treatment was repeated 4 times hence the number of experimental units became 20 units. The parameters observed included bulk density and soil porosity. The research results showed that biochar application significantly reduced the bulk density and significantly increased the soil porosity of Ultisol soil.
\end{abstract}

Keywords: oil palm plants residue; biochar; soil physical properties; Ultisol

Reference to this paper should be made as follows :

Rusdi, I. A. Rauf, Supriadi, and B. Hidayat. 2019. Application of biochar from palm oil plants residues on physical properties of Ultisol. Agritropica: Journal of Agricultural Science. 2(2) :9397. Doi: https://doi.org/10.31186/Jagritropica.2.2.93-97

\section{INTRODUCTION}

Ultisol soil is one type of soil that has severe obstacles in supporting plant growth,the extent of its total land area in Indonesia ranges from $25 \%-27 \%$ (Subagyo et al., 2004). Ultisol has low aeration pore and soil stability index hence the soil easily becomes dense and is sensitive to erosion. As a result, plant root growth is inhibited due to the permeability of roots into the soil is blocked (Subowo et al., 2012).

Improvements on soil physical properties need to be done because the soil physical properties have many uses in supporting other soil properties, especially in supporting the movement of roots in the soil. The usefulness of soil physical properties is being able to support the plants above it, the capacity to store water, the ease of being penetrated by roots, aeration and drainage in the soil and the ability of the soil to retain nutrients. All of these things are very closely related to the soil physical condition (Foth, 1984).

One way to improve soil physical properties is by biochar application because biochar has the ability to retain water hence it can increase the availability of water in the soil.Based on the research results by Nurida (2014), the most effective soil conditioner in reducing bulk density is by using biochar. Based on this research results, initial soil bulk density (BD) was 1.41 $\mathrm{g} / \mathrm{cm}^{-3}$, decreased to $1.30-1.40 \mathrm{~g} / \mathrm{cm}^{-3}$ after the application of biochar into the soil. Based on the research results of Aslam et al (2014), it was shown that biochar application was able to improve soil physical properties, but depending 
on the type of biochar (depending on the pyrolysis conditions and type of biomass) used, the type of soil where biochar was applied and the biochar doses.

In addition, biochar is also better than compost as a soil conditioner or in improving soil properties. According to Steiner et al (2007) biochar as a soil conditioner has recalcitrant properties, is more resistant to oxidation and is more stable in soil. Biochar in the soil can survive for a long time because biochar is difficult to decompose (Lehmann and Joseph, 2009). Biochar also improve soil chemical properties and absorb heavy metal to be an active in soil (Hidayat et al. 2018)

Biochar is able to increase soil pores due to the characteristic of porous biochar which increases soil pores. In addition, biochar which has a more porous pore structure has less ash content compared to biochar which has a pore structure that has less shaft. Biochar is also able to provide a new habitat for soil microbes hence it can affect the increase in soil pores (Zhaeittun, 2016).

The purpose of this research was to determine the effect of various application of biochar made of oil palm plants residue in improving the physical properties of Ultisol soil.

\section{MATERIALS AND METHODS}

This research was carried out in the Faculty of Agriculture greenhouse, University of Sumatera Utara, Medan. The results of initial soil analysis showed that the soil had $0.98 \%$, C-Organic, 4.8 $\mathrm{H}_{2} \mathrm{O}$ pH, 1.20 g.cm-3 bulk density, 54.50\% porosity and sandy clay texture.

This research used a non-factorial Completely Randomized Design with 5 treatments namely Control (K), Oil Palm
Stem Biochar (BB), Oil Palm Frond Biochar (BP), Oil Palm Empty Fruit Bunches Biochar (BT) and Combinations of all three biochar (BK). Then 4 replications were carried out in each treatment.

Doses application was based on the amount of organic matter contained in the soil as much as 3\%, then incubated for 8 weeks. The parameters observed were bulk density, soil porosity, soil permeability. Soil sample used was undisturbed soil, which was taken using a sample ring. Available water was calculated from the difference in soil water content pF 2.5 and pF 4.2. Data analysis using ANOVA and DMRT test with a level of $5 \%$.

Table 1. Characteristic of Galang Ultisol

\begin{tabular}{lll}
\hline Parameter & Value & Criteria \\
\hline $\mathrm{pH} \mathrm{H} \mathrm{H}_{2} \mathrm{O}$ & 4,8 & Acid \\
$\mathrm{pH} \mathrm{KCl}$ & 4,7 & Neutral \\
$\mathrm{C}$ organic & $0,98 \%$ & Low \\
Water Content & $12 \%$ & - \\
Bulk Density & 1,20 & Good \\
& $\mathrm{g} / \mathrm{cm}^{3}$ & \\
Porosity & 54,50 & Good \\
Soil Texture & - & Sandy Clay \\
\hline
\end{tabular}

\section{RESULTS AND DISCUSSION}

\section{Bulk Density}

Based on the measurement data of bulk density (Figure 1), and from the results of analysis of variance, it was found that biochar application had a significant effect in decreasing the bulk density. Based on figure 1, it can be known that the lowest bulk density was in the treatment of BP (Oil Palm Frond Biochar) with a bulk density of 1.02 $\mathrm{g} / \mathrm{cm}^{3}$. Whereas the highest bulk density 
was found in treatment $\mathrm{K}$ (Control) of $1.19 \mathrm{~g} / \mathrm{cm} 3$.

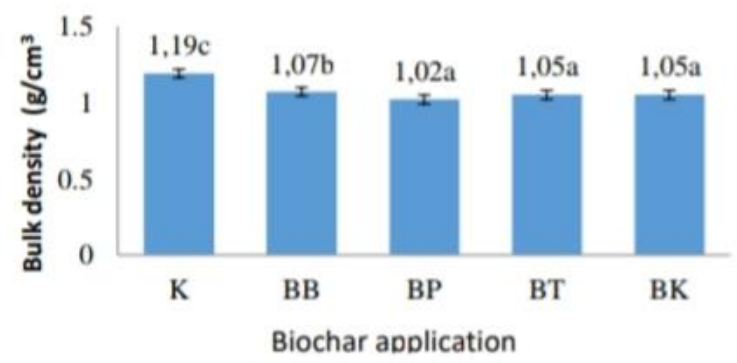

Note: Numbers followed by the same letters are not significantly different $(5 \%)$ according to the DMRT test.

Figure 2. Bulk density value due to the application of biochar made from oil palm plant residue.

Biochar application from several types of oil palm residuals material can significantly reduce the bulk density in the treatment of BP (Biochar of oil palm fronds), BT (Biochar of oil palm empty fruit bunches) and BK (combination of biochars). However, for the treatment of BB (Oil Palm Stem Biochar) it can reduce the bulk density but not significantly. This was in accordance with the research conducted by Verheijen et al. (2010) which stated that the biochar application can increase the surface area of the soil thereby increasing the pore space in the soil. According to Masulili et al. (2010) biochar has a porous property which increases the pore space in the soil.

\section{Porosity}

Based the data of soil porosity measurement (Figure 2) and analysis of variance results, it was obtained that the biochar application had a significant effect on increasing soil porosity.

Based on figure 2, it can be known that the lowest porosity was in treatment
$\mathrm{K}$ (Control) of $54.75 \%$. Whereas the highest soil porosity was found in treatment BP (Oil Palm Fronds Biochar) of $61.5 \%$.

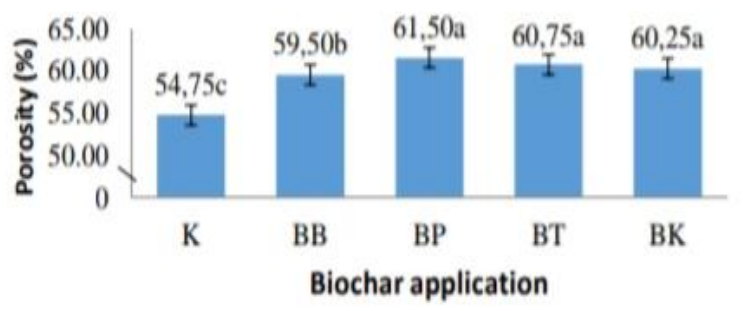

Note: Numbers followed by the same letters are not significantly different $(5 \%)$ according to the DMRT test.

Figure 2. Soil porosity value due to the application pf biochar made of oil palm plants residue

Biochar application from several types of materials can significantly improve soil porosity in the treatment of BP (Biochar of oil palm frond), BT (Biochar of oil palm empty fruit bunches) and BK (combination of biochar). But for treatment BB (Oil Palm Stem Biochar) increases soil porosity but not significantly. Foth (1984) stated that porosity is a ratio between the density of soil mass and the density of soil particles, therefore it can be said that in a volume of soil consists of soil mass and soil pore space. Thus, soil with low mass density has a lot of pore space, and vice versa. Hence, the existence of the pore space in the soil determines the size of the mass density of the soil (Sopher and Baird, 1982).

\section{Soil Permeability}

The application of biochar from several types of materials did not significantly affect the permeability of Ultisol soils (Figure 3). Based on figure 3, 
the highest soil permeability was found in treatment $\mathrm{K}$ (Control), which was $24.92 \mathrm{~cm} \mathrm{/} \mathrm{hour.} \mathrm{The} \mathrm{lowest} \mathrm{average}$ permeability value was found in BB (biochar stem) which was equal to 17.90 $\mathrm{cm} /$ hour.

Biochar application from various materials had no effect on soil permeability, but in general it can reduce soil permeability. This was in accordance with the research conducted by Ardiyani et al (2015), the application of biochar on clay-dominated land causes an increase in the ability of soil to bind water.Thus increasing water retention can be offset by a decrease in soil permeability.

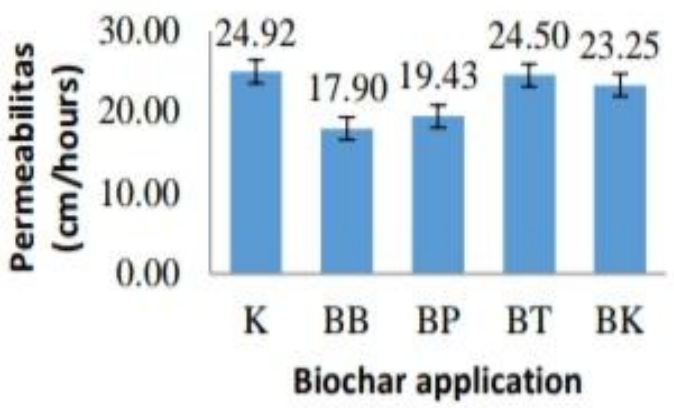

Figure 3. Soil permeability value due to aplication of biochar made of oil palm plants residue.

\section{Water Content}

The application of biochar from several types of materials had not improved groundwater availability (Figure 4).

Based on figure 4, it was known that the highest available water was found in BT treatment (Biochar OPEFB) that was equal to $4.99 \%$. The highest available water value was found in BP (Fronds Biochar) treatment which was equal to $4.14 \%$.

Biochar application from several types of materials did not affect the availability of groundwater. One factor that affects the availability of water in the soil is the texture of the soil.Soil texture greatly affects the ability of the soil in retention of water (Aslam et al., 2014). Galang Ultisol soil has a sandy clay texture where the soil has dominant with sand hence the ability of the soil to hold water is low. According toNurida (2014), oil palm shell biochar has high ability to absorb water up to > 50\% volume, but it is not balanced with the ability to store it because of the rapid loss of water. This condition causes biochar application to have no significant effect on the availability of water in Ultisol soil.

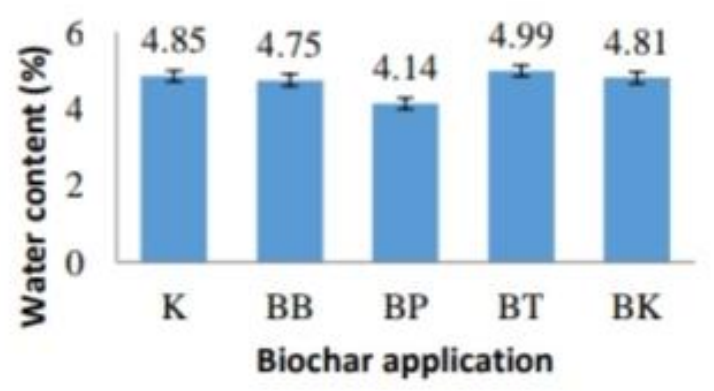

Figure 4. the value of available water in Ultisol soil due to the aplication of biochar made of oil palm plants residue.

\section{CONCLUSION}

Application of biochar made of oil palm plants residue can reduce bulk density and increase porosity. The materials of oil palm fronds, oil palm empty fruit bunches and all three combinations were higher in reducing the bulk density and increasing soil porosity compared to oil palm stems.

\section{REFERENCES}

Ardiyani, R. R., Sutono, dan S. Prijono. 2015. Perbaikan retensi air typic kanhapludult taman Bogor dan pertumbuhan tanaman jagung 
tempurung kelapa sawit. JurnalTanah dan Sumberdaya Lahan. 2 (2): 199-209

Aslam, Z., Muhammad, K., Muhammad A, 2014. Impact of Biochar on Soil Physical Properties Scholarly Journal of Agricultural Science. 4(5), pp. 280-284

Foth, H. D., 1984. Fundamentals of Soil Science Seventh Edition. John Wiley and Sons, New York.

Hidayat, B., A, Rauf., T, Sabrina. 2018. Potential of Several biomass as Biochar Adsorben. Journal of Asian Scentific Research. 8(11) 293-300.

DOI:10.18488/journal.2.2018

Lehmann, J. and S. Joseph. 2009.

Biochar for Environmental

Management. Earthscan,

London.

Masulili, A., W. H. Utomo, and M. S. Syechfani. 2010. Rice Husk

Biochar for Rice Based Cropping System in Acid Soil. Journal of Agricultural Science. 2. 39-42.

Subagyo, H., N. Suharta dan A. B. Siswanto. 2004. Tanah-tanah Pertanian di Indonesia. Bogor : Pusat Penelitian Tanah dan Agroklimat. Hlm. 21-66.

Subowo, G. 2012. Empowerment of Soil Biological Resources for Rehabilitation of Degraded Ultisols. Jurnal Sumberdaya Lahan. 6 ( 2): 79-88
Nurida 2014. Potency of utilizing biochar for dry land rehabilitation in Indonesia. Jurnal Sumberdaya Lahan Edisi Khusus, 57-68

Steiner, C., W.G. Teixeira, J. Lehmann, T. Nehls, J.L.V. de Macêdo, W.E.H. Blum, W. Zech. 2007. Long term effects of manure, charcoal and mineral fertilization on crop production and fertility on a highly weathered Central Amazonian upland soil. Plant soil 291: 275-290.

Zhaeittun, P.P. 2016. Pengaruh Biochar terhadap Sifat Fisik Tanah dan Agregat Halus Contoh Tanah Typic Kanhapludults Kebun Percobaan Taman Bogo, Lampung Timur. Skripsi. Fakultas Pertanian, Institut Pertanian Bogor. Bogor.

Verheijen F, S. Jeffery, A.C. Bastos, M. van der Velde, I. Diafas. 2010. Biochar Application to Soil. European Commission, Joint Research Centre Institute for Environment and Sustainability Luxembourg: Office for Official Publications of the European Communities ISBN 978-92-7914293-2

Sopher, C. D and J. V. Baird. 1982. Soils and Soil Management. Reston Publishing Company, Inc, Virginia. 